\title{
Solid wastes from the enzyme production as a potential biosorbent to treat colored effluents containing crystal violet dye
}

Patrícia Grassi, Fernanda C. Drumm, Stéfani S. Spannemberg, Jordana Georgin, Denise Tonato, Marcio A. Mazutti, Janaína O. Gonçalves, Marcos L. S. Oliveira, Guilherme L. Dotto \& Sérgio L. Jahn

\begin{abstract}
Sugarcane bagasse, a largely available waste worldwide, was submitted to solid-state fermentation (SSF) using the fungus Metarhizium anisopliae, aiming to produce enzymes. The solid waste generated from SSF was tested as an alternative biosorbent to treat colored effluents containing crystal violet (CV) dye. The biosorbent, here named BW (bagasse waste), was characterized, and experimental tests were performed to verify the influence of $\mathrm{pH}$ and dosage on the $\mathrm{CV}$ biosorption. Isotherms and biosorption kinetics were performed, and the biosorption thermodynamic parameters were determined. The potential of BW was also evaluated for the treatment of a simulated textile effluent. The maximum biosorption capacity was $131.2 \mathrm{mg} \mathrm{g}^{-1}$ at $328 \mathrm{~K}$, and the Liu was the most appropriate model to represent equilibrium data. The biosorption was spontaneous and endothermic. The use of BW in the simulated effluent showed that it is an efficient material, reaching color removal values of $85 \%$. Therefore, the sugarcane bagasse generated from SSF can be considered a potential biosorbent to remove $\mathrm{CV}$ from textile effluents. This finding is relevant from the total environment viewpoint, since, at the same time, SSF generates enzymes and a solid waste, which in turn can be used as biosorbent to treat colored effluents.
\end{abstract}

Keywords: Biomass waste, Biosorption, Crystal violet, Fermentation wastes, Sugarcane bagasse 